F. Reprod. Fert. (1970) 23, 49-53

\title{
A RELATIONSHIP BETWEEN THE DURATION OF OESTRUS, OVULATION RATE AND LITTER SIZE OF SHEEP
}

\author{
R. B. LAND \\ A.R.C. Animal Breeding Research Organisation, \\ West Mains Road, Edinburgh 9 \\ (Received 29th August 1969)
}

\begin{abstract}
Summary. The litter size of Finnish Landrace sheep was found to be positively correlated with the duration of oestrus at the time of mating. The within-year regression of litter size on duration of oestrus was $0.011 \mathrm{lambs} / \mathrm{hr}$ and the correlation between the two traits $0.18(1 \%>$ $P>0.1 \%$ ).

Data from Finnish Landrace $\times$ Blackface, Blackface and Merino $\times$ Blackface females, indicated that the correlation was mediated through ovulation rate, and that it was not limited to the Finnish Landrace.
\end{abstract}

\section{INTRODUCTION}

The duration of oestrus in the sheep has been found to differ from one breed to another (Hafez, 1952; Joubert, 1962), but Asdell (1964) concluded that "the mean heat period (of the sheep) is from 30 to 36 hours, with little differences between breeds". The Finnish Landrace, however, has been found by Donald \& Read (1967) to have an oestrous period of 48 to $72 \mathrm{hr}$, much longer than that of British breeds. They also confirmed the earlier observation of Maijala (1966) that the litter size of the Finnish Landrace ewe is larger than that of British sheep.

As a result of this indication that the duration of oestrus and the subsequent litter size may be positively correlated in the sheep, the relationships between these parameters were investigated further and the results are presented in this communication.

\section{MATERIALS AND METHODS}

A flock of Finnish Landrace sheep was established at the Animal Breeding Research Organisation's (ABRO) Blythbank farm in Peeblesshire in 1962. During mating periods, the females were run with a teaser ram and examined twice daily ( 08.00 and 16.00 hours) for the onset of oestrus. Females on heat were withdrawn and mated twice daily until the end of oestrus. The number of matings, the day of lambing and the litter size were recorded for each ewe mated from 1962 to 1968 . The duration of oestrus was then estimated from the number of times an individual was mated and the gestation length checked. 
During the course of another experiment, the duration of oestrus was measured in a group of Finnish Landrace $\times$ Blackface, Blackface and Merino $\times$ Blackface females, and the number of corpora lutea present in their ovaries counted at laparotomy 5 days later.

\section{RESULTS}

The data from the Finnish Landraces were analysed within years, and the best estimate of the within-year regression of number born on duration of oestrus, and the correlation between these traits obtained by analysis of co-variance. These estimates were obtained separately for animals which were less than 1 year old at the time of mating, more than 1 year old at the time of mating, and for all ewes together. The results are summarized in Table 1, and the joint distribution of litter size and duration of oestrus given in Table 2. There is a

\section{TABLE 1}

THE MEAN DURATION OF OESTRUS AND LITTER SIZE OF FINNISH LANDRAGE FEMALES OF DIFFERENT AGES TOGETHER WITH THE RELATIONSHIPS BETWEEN THESE TRAITS

\begin{tabular}{|c|c|c|c|c|c|}
\hline $\begin{array}{l}\text { Age at } \\
\text { mating }\end{array}$ & No. & $\begin{array}{c}\text { Mean duration } \\
\text { of oestrus } \\
(h r)\end{array}$ & $\begin{array}{l}\text { Mean litter } \\
\text { size }\end{array}$ & $\begin{array}{c}\text { Regression of } \\
\text { litter size } \\
\text { on duration of } \\
\text { oestrus }\end{array}$ & $\begin{array}{c}\text { Correlation } \\
\text { between litter } \\
\text { size and duration } \\
\text { of oestrus }\end{array}$ \\
\hline $\begin{array}{l}<1 \text { year } \\
>1 \text { year } \\
\text { All ewes }\end{array}$ & $\begin{array}{r}61 \\
199 \\
260\end{array}$ & $\begin{array}{l}51 \cdot 16 \\
51 \cdot 53 \\
51 \cdot 45\end{array}$ & $\begin{array}{l}1 \cdot 97 \\
2 \cdot 86 \\
2 \cdot 65\end{array}$ & $\begin{array}{c}-0.004 \mathrm{NS} \\
0.009^{*} \\
0.011^{* *}\end{array}$ & $\begin{array}{c}-0.06 \mathrm{NS} \\
0.16^{*} \\
0.18^{* *}\end{array}$ \\
\hline
\end{tabular}

TABLE 2

THE BIVARIATE DISTRIBUTION OF DURATION OF OESTRUS AND LITTER SIZE IN FINNISH LANDRAGE FEMALES OF ALL AGES

\begin{tabular}{|c|c|c|c|c|c|c|c|}
\hline $\begin{array}{l}\text { Duration of } \\
\text { oestrus }(h r)\end{array}$ & 1 & $2_{2}^{\text {No. }}$ & $\begin{array}{c}f \operatorname{lamb} b \\
3\end{array}$ & born & 5 & $\begin{array}{l}\text { Total no. } \\
\text { of ewes }\end{array}$ & $\begin{array}{l}\text { Mean no. } \\
\text { of lambs/ } \\
\quad \text { ewe }\end{array}$ \\
\hline $\begin{array}{l}13 \\
25 \\
37 \\
49 \\
61 \\
73 \\
85 \\
97\end{array}$ & $\begin{array}{l}3 \\
2 \\
7 \\
9\end{array}$ & $\begin{array}{r}4 \\
11 \\
17 \\
34 \\
20 \\
5 \\
2\end{array}$ & $\begin{array}{r}1 \\
7 \\
9 \\
40 \\
33 \\
12 \\
4 \\
1\end{array}$ & $\begin{array}{r}1 \\
1 \\
15 \\
7 \\
6\end{array}$ & $\begin{array}{l}2 \\
1 \\
3 \\
1\end{array}$ & $\begin{array}{r}5 \\
24 \\
30 \\
96 \\
73 \\
24 \\
7 \\
1\end{array}$ & $\begin{array}{l}2 \cdot 20 \\
2 \cdot 50 \\
2 \cdot 40 \\
2 \cdot 66 \\
2 \cdot 64 \\
3.04 \\
3.00 \\
3.00\end{array}$ \\
\hline Total no. of ewes & 21 & 93 & 109 & 30 & 7 & 260 & $2 \cdot 65$ \\
\hline $\begin{array}{l}\text { Mean duration } \\
\text { of oestrus/ewe }\end{array}$ & $49 \cdot 6$ & $47 \cdot 1$ & $54 \cdot 5$ & $55 \cdot 4$ & $50 \cdot 7$ & $51 \cdot 45$ & \\
\hline
\end{tabular}

statistically significant positive relationship between the duration of oestrus and the number of lambs subsequently born for ewes greater than 1 year of age at the time of mating and for all ewes combined, the litter size increasing by 
approximately one-tenth of a lamb for every 10 extra hours in oestrus. In the case of the pooled estimate, however, better estimates of the relationship between the two traits were obtained by examining each year separately than by using the overall estimate.

Another aspect of the relationship between the two traits was obtained by comparing the duration of infertile oestrous periods with the subsequent fertile ones. Seventeen of the 260 pregnancies examined above were initiated at the second or third mating of the season, the remaining 243 conceptions following the first mating. The mean length of the infertile heats of the seventeen ewes was $35.2 \mathrm{hr}$, compared to $49.7 \mathrm{hr}$ for the same ewes at the following fertile heats. The infertile heats being significantly shorter $(t=2.36 ; 5 \%>P>1 \%)$ than the subsequent fertile ones.

\section{TABLE 3}

THE DURATION OF OESTRUS AND THE NUMBER OF CORPORA LUTEA PRESENT IN THE OVARIES OF FINN $\times$ BLAGKFACE, BLACKFACE, AND MERINO $\times$ BLACKFACE EWES

\begin{tabular}{l|c|c|c}
\hline $\begin{array}{c}\text { Breed or cross } \\
\text { of ewe }\end{array}$ & No. of ewes & $\begin{array}{c}\text { Mean duration of } \\
\text { oestrus }(h r)\end{array}$ & $\begin{array}{c}\text { Mean no. of } \\
\text { corpora lutea }\end{array}$ \\
\hline Finn $\times$ Blackface & 7 & 52.45 & 1.86 \\
Blackface & 6 & 42.90 & 1.33 \\
Merino $\times$ Blackface & 7 & 28.16 & 1.14 \\
\hline Least significant difference $(P<5 \%)$ & 13.38 & 1.02 \\
\hline
\end{tabular}

The duration of oestrus and number of corpora lutea formed in Blackface, Finnish Landrace $\times$ Blackface and Merino $\times$ Blackface females are given in Table 3, together with the least significant difference $(5 \%>P>1 \%)$. It can be seen that the ovulation rates and durations of oestrus are ranked in the same order for the three types of ewe, the longest oestrus being associated with the highest ovulation rate in the Finnish Landrace crosses and vice versa in the Merino crosses.

\section{DISCUSSION}

The analysis of the Finnish Landrace pregnancies indicates that in addition to the Finnish Landraces having longer oestrous periods and larger litters than British breeds there is also a positive relationship between these two traits within the Finnish Landrace breed.

The litter sizes of the Finnish Landrace and Merino $\times$ Blackface ewes were found to be 2.3 and 1.2 respectively (Donald, Read \& Russell, 1968) compared to 1.9 for the Blackface (Wiener, 1967). The difference of 1.1 lambs per ewe between the crossbreds has not been wholly reflected in the difference in number of corpora lutea observed in this study. The smaller difference and lower absolute values recorded here could, however, be due to the fact that these observations were made in late December, whereas the normal mating time is early November, the fecundity declining as the breeding season advances in a similar way to that observed in Clun ewes by Land, Dickinson \& Read (1969). The identical ranking of litter size, ovulation rate and the duration of 
oestrus in these three types of sheep, however, indicates that the relationship between duration of oestrus and subsequent litter size is mediated, at least partly, through ovulation rate. This conclusion is supported by the observation of J. E. Newton at the Grassland Research Institute, Hurley (personal communication), that there was a positive, though again, statistically insignificant regression of ovulation rate and litter size on duration of oestrus following the treatment of Scottish half bred ewes with pregnant mares' serum gonadotrophin. The regressions, 0.013 corpora lutea/hr and $0.015 \mathrm{lambs} / \mathrm{hr}$ respectively, were both of a similar order of magnitude to those observed in the Finnish Landrace sheep. The observation that the Merino cross reduced these three parameters relative to the Blackface in the same way that the Finnish Landrace cross raised them, shows that the positive relationship between the parameters is not solely restricted to Finnish Landrace and Finnish Landrace cross sheep.

Comparisons of purebred and crossbred ewes suggest that high ovulation rate, long oestrus and large litters are genetically correlated. However, within the Finnish Landrace breed, the correlation of duration of oestrus and litter size is so small that it can account for only a small part ( 3 to $4 \%$ ) of the total variation in both characters and even that probably has an environmental component.

In this study, the duration of oestrus and the number of matings are confounded and it is possible that the greater number of matings experienced by the ewes with longer oestrous periods may lead to the ovulation of a greater number of follicles or the fertilization of a greater proportion of the eggs shed. The indication that the correlation between the duration of oestrus and subsequent litter size is mediated through ovulation rate rather than differential embryonic mortality, however, suggests that the longer oestrous period of the ewe which subsequently produces a large litter is due to an increase in the output of ovarian steroids and not to the greater sensitivity of those ewes to steroids. Even so, the longer oestrus could be caused by an increased conditioning of the ewes to oestrogen by the higher output of progesterone from the corpora lutea of the previous oestrus (as discussed by Robinson (1959) in terms of the incidence and time of onset of oestrus in ovariectomized ewes following treatment with different combinations of progesterone and oestrogen), or to the presence of oestrogen, in sufficient quantities to induce oestrus, for a longer period of time. Again, the presence of oestrogen for a longer period of time in the more fecund ewe could either follow an extension of the time during which ovulation and oestrogen secretion takes place, or the gradual elimination of the greater amounts of oestrogen secreted simultaneously by the larger number of developing follicles.

\section{ACKNOWLEDGMENTS}

I wish to thank Mr E. Hughes and the Blythbank staff for collecting the Finnish Landrace data, and Mr J. D. Barker for maintaining the records.

\section{REFERENCES}

AsDels, S. A. (1964) Patterns of mammalian reproduction. Constable, London.

Donald, H. P. \& ReAd, J. L. (1967) The performance of Finnish Landrace sheep in Britain. Anim. Prod. 9, 471. 
Donald, H. P., Read, J. L. \& Russell, W. S. (1968) A comparative trial of crossbred ewes by Finnish Landrace and other sires. Anim. Prod. 10, 413.

HAFEZ, E. S. E. (1952) Studies on the breeding season and reproduction of the ewe. F. agric. Sci., Camb. 42, 232.

Joubert, D. A. (1962) Sex behaviour of purebred and crossbred Merino and Blackhead Persian ewes. 7. Reprod. Fert. 3, 41.

Land, R. B., Dickinson, A. G. \& Read, J. L. (1969) The influence of seasonal variation on fertility and early body growth in sheep. Anim. Prod. 11, 251.

Majjala, K. (1966) Causes of variation in litter size of Finn-sheep ewes. 9th Int. Congr. Anim. Prod., Edinburgh. Abstracts, p. 29.

Rosinson, T. J. (1959) The oestrous cycle of the ewe and doe. In: Reproduction in Domestic Animals, Vol. 1, p. 291. Eds. H. H. Cole and P. T. Cupps. Academic Press, New York and London.

Wiener, G. (1967) A comparison of the body size, fleece weight and maternal performance of five breeds of sheep kept in one environment. Anim. Prod. 9, 177. 